\title{
ANALISIS SISTEM MANAJEMEN PEMBELAJARANTATAP MUKA PADA MASA PANDEMI COVID-19 DI STIE EL HAKIM
}

\author{
HANE JOHAN, HELENDRA, HADERAH
}

hanejohan@ymail.com

\begin{abstract}
The aims of this study were to: (1) obtain the best methods and techniques in the limited face-to-face learning management system at the El Hakim College of Economics (STIE); (2) provide advice to the campus management team in order to improve the quality of learning during the covid 19 pandemic; (3) provide advice to educators and education staff in the context of improving face-to-face learning management during the covid 19 pandemic. The method used in this paper is a qualitative method with a literature review approach and participant responses via google form to students and lecturers at the El Hakim College of Economics (STIE). In the analysis using the problem tree approach, target tree, solution tree/alternatives in getting the expected results. The results show that the impact of a learning management system that is suitable for campus conditions can provide convenience, effective time, and efficient costs for students and lecturers in achieving learning objectives.
\end{abstract}

Keywords: learning management, face-to-face learning, pandemic covid 19

\begin{abstract}
Abstrak: Tujuan penelitian ini untuk : (1) memperoleh metode dan teknik terbaik dalam sistem manajemen pembelajaran tatap muka terbatas di Sekolah Tinggi Ilmu Ekonomi (STIE) El Hakim; (2) menjadi sumbang saran kepada tim majemen kampus dalam rangka perbaikan mutu pembelajaran selama pandemi covid 19; (3) menjadi sumbang saran kepada tenaga pendidik dan tenaga kependidikan dalam rangka perbaikan manajemen pembelajaran tatap muka selama pandemik covid 19. Metode yang digunakandalam penulisan ini adalah metode kualitatif dengan pendekatan literatur review dan respon partisipan lewat google form kepada mahasiswa/i dan dosen-dosen di Sekolah Tinggi Ilmu Ekonomi (STIE) El Hakim. Dalam analisis memamfaatkan pendekatan pohonmasalah, pohon sasaran, pohon solusi/alternatif dalam mendapatkan hasil yang diharapakan. Hasilnya menunjukkan bahwa dampak sistem manajemen pembelajaran yang sesuai kondisi kampus dapat memberikan kemudahan, waktu yang efektif, dan biaya yang efisien bagi mahasiswa/i dan dosen dalam pencapaian tujuan pembelajaran.
\end{abstract}

Kata Kunci: manajemen pembelajaran, pembelajaran tatap muka, pandemic covid 19

\section{A. Pendahuluan}

Wabah virus covid-19 telah berlangsung lebih setahun dan belum ada tanda-tanda wabah akan berakhir. Menurut WHO, ada 200 negara yang terkonfirmasi terdampak wabah virus covid-19, tak terkecuali Indonesia. Hampir seluruh sektor kehidupan terkena dampak wabah virus covid-19, termasuk sektor pendidikan yang merupakan sektor yang paling terasa. Anakanak harus belajar dari rumah dan dosen-dosen harus mengajar dari rumah sehingga tidak ada interaksi dengan baik yang akan berdampak pada mutu pendidikan. Pemerintah melalui Kemdikbud menerapkan kebijakan belajar dari rumah (BDR) untuk satuan pendidikan yang berada di wilayah zona kuning, oranye, dan merah. Sedangkan bagi satuan pendidikan yang berada di zona hijau, dapat melaksanakan pembelajaran tatap muka terbatas dengan tetap memperhatikan protokol kesehatan.

Sekolah Tinggi Ilmu Ekonomi (STIE) El Hakim melakukan tatap muka terbatas sejak minggu pertama bulan September 2020 dengan sistem 2 shif, setiap shif ada 15 sampai 18 mahasiswa/i yang berada di dalam satu kelas. Jam tatap muka 150 menit perhari dibagi dalam dua jam mata kuliah, sehingga tiap mata mata kuliah berlangsung 50 menit. Dalam setiap pembelajaran tatap muka di masa pandemi kendala yang dihadapi adalah durasi waktu yang panjang untuk dosen dan durasi waktu yang pendek untuk peserta didik akibat dari 
pembagian shif setiap kelas. Kendala lainnya jika pembelajaran campuran tatap muka - online atau sistem blanded learning adalah infrastruktur di kampus belum memadai dan kesiapan dosen menggunakan alat pendukung lainnya belum memadai. Kendala-kendala tersebut akan berpengaruh terhadap mutu pendidikan di Sekolah Tinggi Ilmu Ekonomi (STIE) El Hakim.

Memperhatikan kendala-kendala di atas maka dengan penuh kesadaran yang tinggi dari dosen-dosen dan tim menajemen Sekolah Tinggi Ilmu Ekonomi (STIE) El Hakim harus mencarikan solusi terbaik untuk mengatasi kendala-kendala yang dihadapi selama proses pembelajaran tatap muka terbatas selama pandemi covid 19. Dengan memperhatikan kondisikondisi real yang ada di Sekolah Tinggi Ilmu Ekonomi (STIE) El Hakim, salah satu langkah yang tepat dilakukan pihak kampus adalah memperlakukan sistem manajemen pembelajaran campuran, yaitu sistem pembelajaran tatap muka terbatas guna menjelaskan materi-materi ajar yang sulit dijelaskan lewat platform-platform pembelajaran tatap muka online seperti Google Meet, Zoom, atau Teams. Sedangkan untuk admistrasi pembelajaran seperti penggiriman ataupun pengumpulan tugas, dan tanya jawab ataupun sharing materi, serta evaluasi dapat dengan muda dilaksanakan di google classroom ataupun moodle. Sistem pembelajaran campuran seperti ini belum semua dosen melakukan di Sekolah Tinggi Ilmu Ekonomi (STIE) El Hakim akibat keterbatasan dalam penguasaan TIK dengan baik.

Proses pembelajaran tatap muka terbatas memerlukan pengelolaan pembelajaran yang baik. Kata pengelolaan sepadan dengan kata manajemen yang berasal dari bahasa inggris "Managaments", yang berarti tata laksana dan tata pimpinan. Erwinsyah, A. (2017:71), "pengelolaan adalah proses perencanaan, pengorganisasian, kepemimpinan, dan pengendalian semua sumber daya organisasi untuk mencapai tujuan yang telah ditetapkan". Pengertian sistem manajemen pembelajaran adalah salah suatu cara untuk mengatur aktivitas pembelajaran berdasarkan prinsip pembelajaran bermakna guna mencapai tujuan pembelajaran sehingga dapat tercapai secara efisien dan efektif. Efisien mengandung pengertian proses yang dilakukan untuk menghemat sumber daya seperti menghemat tenaga, waktu, dan biaya, sedangkan efektif mengandung pengertian hasil yang sesuai harapan. Fakhrurrazi, F. (2018:92), "untuk menciptakan kondisi pembelajaran yang efektif, dosen dituntut agar mampu mengelola proses pembelajaran yang memberikan rangsangan kepada mahasiswa/i sehingga ia mau dan mampu belajar secara aktif. Dari pengertian di atas dapat disintesakan bahwa manajemen pembelajaran yang baik merupakan situasi yang diciptakan dosen dan kampus yang memungkinkan mahasiswa/i dapat secara aktif memperoleh pengetahuan dari berbagai sumber belajar.

Dosen yang efektif akan mempertimbangkan kebutuhan pebelajar, mengorganisasikan dan mengelola kelas dengan baik, menyediakan sumber-sumber dan bahan pembelajaran yang sesuai, dan membimbing pebelajar dalam kegiatan pembelajaran. Hal ini tidak terlepas dari sumber daya manusia, Darmawati. Y.S (2013:2) "pendidikan disebut bermutu dari segi proses jika proses belajar mengajar berlangsung secara efektif, peserta didik mengalami proses". Untuk mendapat dosen yang bermutu sangat diperlukan pengembangan kompetensi dosen secara berkesinambungan lewat pelatihan-pelatihan yang berkaitan dengan kompetensi pedagogik dosen. Dosen merupakan faktor penentu tinggi rendahnya kualitas hasil pendidikan di kampus. Menurut Nadeak B. (2019:103), "dosen memegang peranan yang amat strategis serta memiliki tanggung jawab yang besar terhadap keberhasilan proses pendidikan itu sendiri". Dari uraian ini dapat katakan bahwa kemampuan dosen dalam mengelola pembelajaran memegang peran yang amat strategis dalam peningkatan mutu pembelajaran di kampus.

Pada masa pandemi covid 19, manajemen pembelajaran terasa sangat sulit akibat terlalu banyak kendala-kendala seperti waktu yang sangat terbatas, media belajar yang belum dimaksimalkan, kemampuan TIK dosen masih kurang, sarana dan prasarana yang belum memadai di kampus. Kendala-kendala seperti ini menjadi perhatian semua pihak di kampus sehingga tidak terjadi kemerosotan mutu pendidikan lebih dalam. Kuliah secara tatap muka terbatas di dalam kelas sangat diperlukan dosen untuk berinteraksi secara langsung dengan 
mahasiswa/i agar hubungan emosional dosen dan mahasiswa/i tetap terjalin dengan baik. Lewat pembelajaran tatap muka di dalam dapat diperoleh mamfaat lebih dalam hal berkolaborasi dalam belajar, berdiskusi, berlatih, dan bermain peran terasa lebih hidup dan bersemangat, dengan bimbingan dari seorang dosen. Tetapi karena waktu sangat terbatas maka diperlukan cara lain untuk bisa mengelola pembelajaran yang efisien dan efektif yaitu menggunakan platform pembelajaran berbasis e-learning seperti google classroom atau moodle.

Hal-hal yang berkaitan dengan share materi, diskusi online, chatting, penyelenggaraan evaluasi dapat dilakukan dengan baik pada Google Classroom. Menurut Ratnawati, H., \& Sulisworo, D (2021:138), "Google Classroom mampu mengatasi keterbatasan ruang dan waktu serta memudahkan pendidik untuk mengevaluasi dan memantau setiap kegiatan pembelajaran peserta didik sehingga membuat pembelajaran lebih efektif dan efisien". Pembelajaran online learning dengan memamfaatkan teknologi sebagai media pembelajaran dapat memberikan kemudahan dalam mengelola kelas dan membuat pembelajaran menjadi efektif dan efisien. Tantangan dalam pembelajaran online learning adalah kualifikasi dan kompetensi dosen masalah mendasar di setiap tingkat pendidikan formal mengelola pembelajaran (Murniarti, 2020).

Google Classroom adalah platform besutan Google yang disediakan secara gratis untuk digunakan pada lembaga-lembaga non profit seperti kampus dan untuk perorangan. Google Classroom membantu dosen untuk membuat dan mengatur tugas kelas dengan cepat dan mudah, memberikan umpan balik kepada mahasiswa/i langsung secara efisien, dan berkomunikasi bersama mahasiswa/i tanpa terbatas oleh ruang dan waktu. Disamping itu Google Classroom terintegrasi dengan Google Drive sehingga manajemen file-file berupa vidio, materi ajar, absen mahasiswa/i, nilai mahasiswa/i, kuis-kuis, ulangan harian, evaluasi tengah semester, dan evaluasi akhir semester dapat kelola lewat 1 drive. Menurut Wijoyo, H., Riau, S. D., \& Maitreyawira, S. T. A. B. (2021:4), keunggulan dari Google Classroom sebagai Learning Management System (LMS), yaitu: 1) mudah membuat kelas dan settingannya sangat cepat; 2) hemat dan efisiensi waktu; 3) komunikasi dan diskusi sangat muda dilakukan; 4) data tersimpan pada google drive; 5) Berbagi sumber file yang efisien, praktis dan cepat.

Online Learning bukan tanpa kendala, menurut Junior, D. (2021:81) kekurangan belajar online learning yaitu: 1) peserta didik kesulitan mengikuti pembelajaran bagi mereka yang tidak mempunyai perangkat laptop atau smartphone yang memadai; 2) peserta didik kesulitan mengerjakan tugas-tugas jika jaringan internet tidak memadai; 3) tingkat kecurangan peserta didik dalam menyontek sangat tinggi, 4) biaya internet yang masih mahal, 5) pembelajaran kurang menarik karena tidak ada interaksi secara langsung. Dari beberapa pendapat ahli di atas dapat disintesakan bahwa dengan memamfaatkan Google Classroom sebagai learning management system, akan diperoleh beberapa mamfaat, sebagai berikut: 1) komunikasi dua arah dosen-mahasiswa/i sangat mudah dilakukan layaknya belajar dalam ruang kelas; 2) dapat menangani tugas administrasi pendidikan lebih cepat jika learning management system-nya tepat; 3) proses mengajar/belajar dapat dilakukan di mana pun, kapan pun, dan dari perangkat mobile selama ada jaringan internet; 4) pengelolaan pembelajaran sangat hemat dan efisien dari aspek biaya dan waktu; 5) standar keamanan data memenuhi standar keamanan yang tinggi; 6) aplikasinya sangat mudah dioperasikan dan tidak akan mengalami kesulitan saat digunakan, 7) semua data terpusat pada satu drive.

\section{B. Metodologi Penelitian}

Metode yang digunakan dalam penelitian ini adalah metode kualitatif dengan pendekatan literatur review dan respon partisipan lewat google form kepada mahasiswa/i dan dosen-dosen. Analisis data menggunakan pohon masalah, pohon sasaran, dan pohon solusi untuk mendeskripsi masing- masing indikator yang diteliti. Dari indikator yang diteliti didapatkan hubungan sebab akibat antar indikator penyebab masalah dan indikator yang bisa

312 Lembaga Penelitian dan Penerbitan Hasil Penelitian Ensiklopedia $\quad$ E-ISSN: 2657-0300

P-ISSN: 2657-0319 
diintervensi guna menemukan format sistem manajemen pembelajaran terbaik untuk mencapai tujuan pendidikan yang efisen dan efektif. Adapun tujuan penelitian ini adalah mencari format terbaik sistem manajemen pembelajaran yang cocok digunakan di Sekolah Tinggi Ilmu Ekonomi (STIE) El Hakim selama pandemi covid 19. Hasilnya dapat digunakan sebagai rekomendasi kepada tim manajemen kampus dalam pengembangan sistem manajemen pembelajaran yang lebih baik dan dapat diimplementasikan dosen-dosen sebagai sistem manajemen pembelajaran dengan baik.

\section{Hasil dan Pembahasan}

Pola pembahasan dalam penelitian ini menggunakan analisis pohon masalah dan pohon sasaran dalam bentuk yang dinarasikan. Hasil temuan dikomperasikan dengan temuan pada penelitian sebelumnya guna mendapatkan pokok masalah dan mencari solusi yang tepat. Berdasarkan hasil observasi dan survei indikator yang diteliti dari mahasiswa/i dan dosen-dosen di Sekolah Tinggi Ilmu Ekonomi (STIE) El Hakim selama pembelajaran tatap muka terbatas pada masa pandemi covid 19 adalah:

Indikator persepsi mahasiswa/i dan Dosen menggunakan google Classroom.

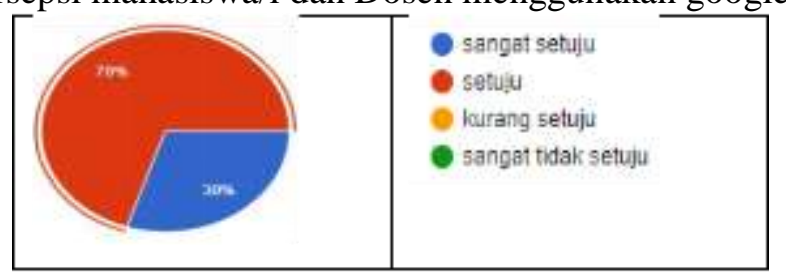

Gambar 1. Persepsi Dosen dan mahasiswa/i dalam menggunakan google classroom.

Pada hasil survei persepsi mahasiswa/i dan dosen sama-sama mayoritas sangat setuju bahwa google classroom muda diakses dengan menggunakan handphone dan laptop dari mana dan kapanpun selama ada jaringan internet. Karena kemudahan google classroom diakses dosen dan mahasiswa/i dari mana dan kapanpun dengan menggunakan HP dan Laptop, maka menjadi aplikasi yang dapat digunakan dosen dalam mengelola sistem pembelajaran tatap muka terbatas dalam hal administrasi pembelajaran. Hal yang berbeda didapat ketika mahasiswa/i ditanya, "Apakah Anda setuju kalau tatap muka di ganti dengan tatap muka virtual dengan menggunakan aplikasi seperti google meet atau teams?", mayoritas mahasiswa/i mengatakan sangat tidak setuju. Alasannya, mahasiswa/i lebih muda mengerti materi perkuliahan dengan tatap muka langsung dosen-mahasiswa/i di dalam ruang kelas. Indikator persepsi mahasiswa/i dan dosen tentang efektifitas dan efisiensi dengan menggunakan google classroom.

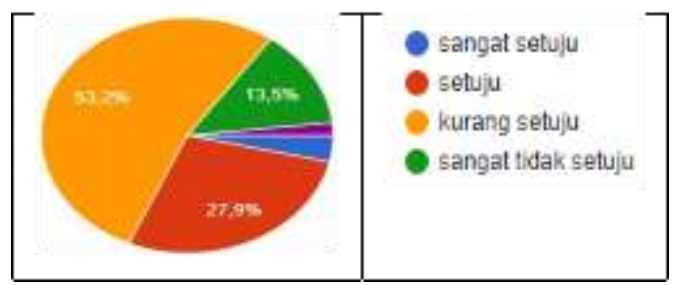

Gambar 2. Persepsi mahasiswa/i dalam efektivitas dan efisiensi menggunakan google classroom.

Pada hasil observasi dan wawancara kepada beberapa mahasiswa/i, diperoleh bahwa mayoritas mahasiswa/i mengatakan belajar lebih efektif dan efisien jika pembelajaran dilakukan tatap muka langsung di dalam ruang kelas dibanding dengan belajar tatap muka secara virtual. Hal yang sama ditemukan pada persepsi dosen, bahwa lebih efektif dan efisien jika materi kuliah disampaikan langsung dalam ruang kelas. Hasil yang berbeda didapat oleh Ratnawati, H., \& Sulisworo, dalam penelitian berjudul "D. Efektivitas E-Learning Berbasis LMS Google Classroom Dengan Strategi Discovery Learning Materi Fluida Statis SMA". Dalam penelitiannya diperoleh hasil bahwa:" pembelajaran Google Classroom dengan strategi Discovery pada materi fluida statis efektif dapat digunakan, dan bisa dilakukan pada mata mata kuliah lain. Bahkan juga berbeda dengan landasan teori yang digunakan 
menurut pendapat Wijoyo, H., Riau, S. D., \& Maitreyawira, S. T. A. B. (2021:4), bahwa keunggulan belajar dengan menggunakan google classroom salah stunya efektif dan efisien. Hasil berbeda diperoleh di Sekolah Tinggi Ilmu Ekonomi (STIE) El Hakim karena terdiri dari mahasiswa/i yang berasal dari daerah-daerah pedalaman yang jaringan internetnya masih morat-marit dan juga dari orang tua dengan golongan tingkat ekonomi keluarga yang beragam. Sehingga sangat menyulitkan dosen dalam meyampaikan materi lewat google classroom.

Indikator persepsi kesulitan dosen dalam menggunakan google classroom.

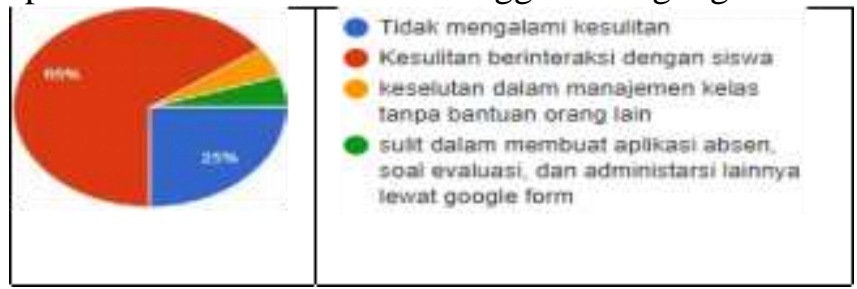

Gambar 3. Persepsi dosen dalam kesulitan menggunakan google classroom.

Dari data diperoleh bahwa dosen umumnya kesulitan berinteraksi dengan mahasiswa/i lewat google classroom dan ada beberapa orang masih kesulitan dalam manajemen kelas dengan menggunakan google classroom. Hal serupa ketika disurvei kepada mahasiswa/i, mayoritas mahasiswa/i mengatakan sangat kesulitan berinteraksi dengan dosen lewat google classroom. Dari 3 indikator di atas dapat diperoleh hasil sebagai berikut: 1) google classroom hanya efektif dan efisien pada sistem manajemen pembelajaran berupa sharing materi, pemberian tugas, pengembalian tugas, dan evaluasi; 2) Pembelajaran tatap muka terbatas di dalam kelas sangat efektif dan efisien untuk pemyampaian materi ajar dan interaksi dengan mahasiswa/i.

\section{Penutup}

Hasil pembahasan dan kajian teori dapat membuktikan bahwa kombinasi google clasroom dan tatap muka terbatas selama pandemi covid 19 dapat efektif dan efisien dari segi proses, biaya, dan waktu untuk sistem manajemen pembelajaran jika dosen menggunakan:1) tatap muka di dalam kelas untuk menyampaikan materi dan berinteraksi dengan mahasiswa/i, dan 2) semua administrasi pembelajaran (absen, sharing materi, pemberian tugas, evaluasi) semua dilakukan lewat google classroom. Tatap muka terbatas terasa sangat tidak efektif dari segi waktu untuk menyampaikan materi kuliah dengan alokasi waktu yang hanya 60 menit per matakuliah. Waktu yang sangat terbatas seperti ini harus dimamfaatkan semaksimal mungkin oleh dosen dalam menjelaskan materi-materi ajar dan berinteraksi dengan mahasiswa/i didalam kelas. Hal-hal yang berkaitan dengan administarsi pembelajaran seperti sharing materi ajar, absen, diskusi, dan evaluasi dapat dilakukan lewat google classroom. Aplikasi google classroom sangat bermamfaat untuk mengelolah kelas secara daring. Sehingga kombinasi kedua sistem yang telah diuraikan di atas dapat menjadi sistem manajemen pembelajaran yang baik.

\section{Daftar Pustaka}

Aldiab. A., Chowdhury, H., Kootsookos, A., Alam, F., \& Allhibi, H. (2019). Utilization of Learning Management Systems (LMSs) in higher education system: A case review for Saudi Arabia. Energy Procedia, 160, 731-737.

Alfina. O. (2020). Penerapan Lms-Google Classroom Dalam Pembelajaran Daring Selama Pandemi Covid-19. MAJALAH ILMIAH METHODA, 10(1), 38-46.

Azhar. K. A., \& Iqbal, N. (2018). Effectiveness of Google classroom: Teachers' perceptions. Prizren Social Science Journal, 2(2), 52-66.

Bernadetha Nadaek (2019). Manajemen Sumber Daya Manusia Pendidikan Era Industri 4.0. Jakarta- UKI Press. 
Cheng, M., \& Yuen, A. H. K. (2018). Student continuance of learning management system use: A longitudinal exploration. Computers \& Education, 120, 241-253.

Erwinsyah, A. (2017). Manajemen Pembelajaran Dalam Kaitannya Dengan Peningkatan Kualitas Dosen. Tadbir: Jurnal Manajemen Pendidikan Islam, 5(1), 69.

Fakhrurrazi, F. (2018). Hakikat pembelajaran yang efektif. At-Tafkir, 11(1), 85-99.

Ghazal, S., Aldowah, H., \& Umar, I. (2017, April). Critical factors to learning management system acceptance and satisfaction in a blended learning environment. In International Conference of Reliable Information and Communication Technology (pp. 688-698). Springer, Cham.

Holloway, I., \& Todres, L. (2003). The status of method: flexibility, consistency and coherence. Qualitative Research, 3(3), 345-357.

Holmes, K. A., \& Prieto-Rodriguez, E. (2018). Student and Staff Perceptions of a Learning Management System for Blended Learning in Teacher Education. Australian Journal of Teacher Education, 43(3), 21-34.

Junior, D. (2021). Implementasi Metode E-Learning Melalui Aplikasi Google Classroom Dalam Mata Mata kuliah Geografi Di Sman 1 Bantarkawung. PROCEEDING UMSURABAYA, 1(1).

Komalasari, R. (2020). Manfaat Teknologi Informasi dan Komunikasi di Masa Pandemi Covid.

TEMATIK-Jurnal Teknologi Informasi Dan Komunikasi, 7(1), 38-50.

Muhardi, M., Gunawan, S. I., Irawan, Y., \& Devis, Y. (2020). Design Of Web Based LMS (Learning Management System) in SMAN 1 Kampar Kiri Hilir. Journal of Applied Engineering and Technological Science (JAETS), 1(2), 70-76.

Shiddiq, M. Z., Marijono, M., \& Imsiyah, N. (2018). Pengaruh Pembelajaran Tatap Muka Terhadap Kemampuan Afektif Warga Belajar Pendidikan Kesetaraan Paket C Di PKBM Suaka Anak Negeri Jember. Learning Community: Jurnal Pendidikan Luar Kampus, 2(1), 14-16.

Ouadoud, M., Nejjari, A., Chkouri, M. Y., \& El-Kadiri, K. E. (2017, October). Learning management system and the underlying learning theories. In Proceedings of the Mediterranean Symposium on Smart City Applications. Springer, Cham.

Ratnawati, H., \& Sulisworo, D. Efektivitas E-Learning Berbasis LMS Google Classroom Dengan Strategi Discovery Learning Materi Fluida Statis SMA. Jurnal Penelitian Pendidikan Fisika, 6(2), 137-145.

Ouadoud, M., Nejjari, A., Chkouri, M. Y., \& El-Kadiri, K. E. (2017, October). Learning management system and the underlying learning theories. In Proceedings of the Mediterranean Symposium on Smart City Applications, Springer, Cham.

Kumar, J. A., \& Bervell, B. (2019). Google Classroom for mobile learning in higher education: Modelling the initial perceptions of students. Education and Information Technologies, 24(2), 1793-1817.

Sudarsana, I. K., Putra, I. B. M. A., Astawa, I. N. T., \& Yogantara, I. W. L. (2019, March). The use of Google classroom in the learning process. In Journal of Physics: Conference Series (Vol. 1175, No. 1, p. 012165). IOP Publishing.

SS, Y. S. D., \& SE, M. (2013). Manajemen pembelajaran dalam upaya meningkatkan mutu pendidikan. Jurnal Mimbar Bumi Bengawan, 6(13). 